\title{
Pathology and pathogenesis of bovine skin and meibomian gland demodicosis
}

\author{
M.T. Abu-Samra ${ }^{1}$ Y.A. Shuaib ${ }^{2,3 *}$
}

\section{Keywords}

Cattle - Demodex - Demodectic mange - Sebaceous gland - Skin Bacteriosis - Pathogenesis - Sudan.

\begin{abstract}
Summary
A national survey on bovine demodicosis was conducted among 48,000 cattle in Sudan during vaccination campaigns $(44,800)$, and at antemortem and postmortem examination in abattoirs (3200). Among the total surveyed, 44,908 were adult (2-8 years) of which $34.6 \%$ were infected, and 3092 were calves ( $<2$ years) of which $34.6 \%$ were infected. Three hundred cattle with severe skin lesions among which 218 also had meibomian gland lesions were selected. The clinical pictures of skin and meibomian gland demodicosis were described. Proteus vulgaris, Pseudomonas aeruginosa, Staphylococcus aureus, Sta. epidermidis, Streptococcus pyogenes (group A) and Trueperella pyogenes were isolated from skin lesions, and Moraxella bovis and Sta. aureus were isolated from meibomian gland lesions. These bacteria produced deleterious toxins and enzymes aggravating the lesions caused by Demodex bovis and D. ghanensis mites in skin and meibomian glands, respectively. Neither mite was found in the internal tissues or organs, indicating that they had no endoparasitic phase. The histopathological changes observed were commensurate with cell-mediated immunity. Liberation of the contents of demodectic mange colonies in the subepidermal and dermal layers of the skin, and surrounding connective tissue of the meibomian glands evoked severe histopathological changes characterized by massive high-turnover granulomatous reactions with influx of macrophages and lymphocytes. The pathogenesis of the disease, from the stage of initial invasion of the hair follicles and collecting tubules of the meibomian glands by the mites and associated bacteria, to the stage of regression of the lesions was described. It was concluded that the nature of association between Demodex mites and bacteria in demodectic mange lesions was synergistic and of equal significance. The high-turnover granulomatous reactions which characterized the histopathological changes showed that Demodex mites and associated bacteria were persistent and immunogenic.
\end{abstract}

1. Department of Veterinary Medicine and Surgery, College of Veterinary Medicine, Sudan University of Science and Technology, PO Box 204 (Hilat Kuku), Khartoum North, the Sudan.

2. Department of Preventive Veterinary Medicine, College of Veterinary Medicine, Sudan University of Science and Technology, PO Box 204 (Hilat Kuku), Khartoum North, the Sudan.

3. Research Center Borstel, Parkallee 18, 23845 Borstel, Germany.

* Corresponding author

E-mail: vet.aboamar@gmail.com

Cell. phone: +49 152182060 08; +249912962961 specific and designated after the name of the host they infest (38, 39). Demodectic mange in cattle is caused by Demodex bovis Stiles $1892(27,44)$. Transmission usually occurs by direct contact from the dam to her offspring during nursing in the neonatal period and never between host animals of different species $(23,31)$.

The cutaneous disease is characterized by the formation of papules, nodules, pustules and cysts of varying sizes $(4,5,39)$. The predilection sites of the lesions seem to be the neck, withers, shoulders and forequarters $(3,5,39)$. As the disease progresses, the lesions spread from their original site to the rest of the body and, in severe infections, most of the skin becomes involved $(5,31,39)$. Many cattle with demodectic mange might have no visible cutaneous lesions and the disease might pass unnoticed. A satisfactory diagnosis of demodicosis can only be made by the demonstration of Demodex mites in the infected purulent material extracted from nodules and pustules $(4,32)$. 
Meibomian glands are also infested by Demodex mites but this demodicosis received the attention of only a few workers. In a recent paper we characterized the ocular lesions (5). Briefly, the disease was characterized by lacrimation, hyperemia and congestion of the mucous membranes, and in extreme cases by purulent exudation, swelling and closure of the eyelids. Demodex ghanensis and the primary pathogenic bacteria - Moraxella bovis and Staphylococcus aureus - were isolated from the infected material extracted from the meibomian gland lesions.

The disease pathology was described in different animals, for example in cattle $(14,30,41)$, dogs $(6,8,43)$, and also in humans

$(7,11)$. Demodectic mange is cosmopolitan and has been reported by many workers in different parts of the world $(38,39)$. However, most of the published works reported the disease in a very limited number of cases. Moreover, most of the authors who studied the pathology of the disease had ignored or undermined the role played by the bacteria associated with the mites in the pathogenesis of the disease. The nature of the association between Demodex mites and the bacteria involved in demodectic mange lesions has not yet been ascertained. For some authors, Demodex mites cause dilatation of the hair follicle and pave the way for secondary bacterial invasion $(15,31,39)$. For others the bacteria are actively introduced in the hair follicles on the exoskeleton or in the gut of the mite $(20,36)$.

In the pathogenesis of a disease, it is interesting to study the fate of both host and pathogen. In the present work, the host-parasite interactions were studied by investigating the pathogen, the clinical manifestation of the disease, host tissue reactions and defensive mechanisms against infection. In this study severe and extensive lesions of demodectic mange were described in a large number of cattle, and most of the parameters concerning the disease have been investigated.

\section{MATERIALS AND METHODS}

\section{Survey}

A national survey of bovine demodicosis was conducted over three years in five states of Sudan during vaccination campaigns or in abattoirs. The total number of cattle surveyed was 48,000 (5) belonging to 189 herds, among which 44,800 cattle were surveyed during vaccination campaigns, and 3200 cattle were examined antemortem and postmortem in abattoirs (1242 infected and 1958 non-infected). Three hundred cattle with severe skin lesions, among which 218 had simultaneously meibomian gland lesions, and 50 non-infected control animals were selected from abattoirs for this study. Non-infected cattle were selected after verifying that they were free of demodectic mange lesions at antemortem examination. This was achieved by running the hand over the shoulders, axillae, brisket and neck, and by rolling the loose skin in the axillae and brisket between the thumb and other fingers as suggested by other authors $(33,39)$. Skin brushings were collected in sterile screw-capped plastic containers from the 50 non-infected control animals using a coarse brush, and two sets of swabs and two impression smears were also collected from the eyes of these animals after examination under a magnifying lens.

Purulent infected material was extracted from the 300 skin and 218 meibomian gland lesions of the infected cattle using sterile techniques. Each specimen of the infected material was divided into two parts. The first part was kept in sterile bijou bottles and refrigerated for bacteriological investigation. The second part was kept in bijou bottles containing equal volumes of glycerol and ethanol for parasitological investigation. The skin brushings, impression smears and swabs from the eyes of the 50 non-infected cattle were refrigerated for both bacteriological and parasitological investigations. Skin biopsy specimens were collected from the 300 infected and 50 non-infected animals (1). After slaughter, the eyelids of the right eye from each of 25 infected and ten non-infected animals were also excised and collected (5). The biopsy and necropsy specimens were fixed in $10 \%$ formal saline for histopathological examination.

A critical postmortem examination was also conducted on the 25 infected and 10 non-infected animals. The following necropsy specimens were collected from each animal: skin, upper and lower eyelids of the left eye, left eyeball, brain, spinal cord, tongue, esophagus, trachea, lung, pleura, heart, pericardium, aorta, diaphragm, spleen, liver, gall bladder, rumen, reticulum, omasum, abomasum, pancreas, omentum, duodenum, small and large intestines, mesentery, caecum, rectum, kidneys, urinary bladder, testes, penis, ovaries, uterus, vagina, salivary glands, muscles (masseter, neck, shoulder, intercostal, belly, hindquarters), lymph nodes (parotid, mandibular, bronchial, mediastinal, mesenteric, prescapular, precrural, popliteal, inguinal and supramammary). To avoid contamination, all necropsy specimens were collected from non-infected animals before infected ones, and necropsy specimens from internal tissues, glands, organs and muscles were collected before sampling the skin, eyelids and eyeballs. The necropsy specimens were rinsed in sterile distilled water and the water was left to drain. The respective glands, tissues, organs and muscles were pooled together and kept in labeled plastic bags at $-20^{\circ} \mathrm{C}$ until investigation.

\section{Parasitological examination}

A small piece from each specimen of infected purulent material from skin and meibomian gland lesions was crushed between two microscope slides and examined. Another piece of the infected material, skin brushings from non-infected control animals and one set of eye impression smear were examined in $20 \%$ potassium hydroxide. Individual mites were isolated (2) and identified. Confirmation of the identification was conducted in the Department of Veterinary Parasitology, Liverpool School of Tropical Medicine, UK, and the Department of Zoology, University of Massachusetts, USA.

\section{Necropsy specimens}

The respective pooled necropsy specimens from the 25 infected and 10 non-infected cattle were digested in $20 \%$ potassium hydroxide solution. Before digestion was performed, the specimens were chopped into small pieces, thoroughly mixed and $25 \mathrm{~g}$ were transferred to $200 \mathrm{ml}$ flasks containing $100 \mathrm{ml}$ of $20 \%$ potassium hydroxide solution. The flasks were placed in a boiling water bath and continuously shaken until the necropsy specimens were completely digested. A drop of the digested material was placed in the middle of a microscope slide, covered with a coverslip and examined for Demodex mites. Ten milliliters of the digested material of each organ was transferred to sterile test tubes and centrifuged at $3000 \mathrm{rpm}$ for three minutes and a drop from the supernatant fluid was also placed in the middle of a microscope slide, covered with a coverslip and examined for mites.

\section{Bacteriological investigations}

Purulent infected material from skin and meibomian gland lesions were cultured. Two milliliters of sterile nutrient broth were added to the purulent infected material in each bottle, and the contents of the bottles were thoroughly mixed using a mechanical shaker. Culture media and media for biochemical tests were prepared according to standard methods and techniques (10). Moreover, 
$\beta$-hemolytic streptococci were subjected to the Lancefield's grouping by the acid extraction technique (10).

Each specimen was cultured under aerobic, anaerobic and increased carbon dioxide conditions at $37^{\circ} \mathrm{C}$ for $24-48$ hours on the following media: nutrient agar, 5\% sheep, bovine or horse blood enriched agar prepared from blood agar base, McConkey's agar and nutrient broth (Oxoid). Moreover, one set of the seeded blood-enriched agar was incubated at $33^{\circ} \mathrm{C}$ in a humid chamber. Pure cultures were obtained through serial subcultures. The pure isolates were biochemically tested according to standard methods and techniques (10). The second set of eye impression smears were stained by Gram's stain and examined.

\section{Histopathological investigations}

A skin biopsy specimen from each of the 300 infected animals and 25 necropsy specimens from the upper and lower eyelids of the right eye of severely infected cattle and 10 non-infected animals were processed, embedded in paraffin wax and sectioned at $5 \mu \mathrm{m}$ before staining with hematoxylin and eosin, and examined following standard methods and techniques (9).

\section{RESULTS}

\section{Survey}

Among the total number of cattle surveyed $(48,000), 16,608$ had skin lesions of demodectic mange (34.6\%), among which 8012 cattle $(48.2 \%)$ also had skin and meibomian gland demodicosis (5). Among the total surveyed, 44,908 were adult (2-8 years) male and female cattle of which 15,537 were infected (34.6\%), and 3092 were calves (up to 2 years) of which 1071 were infected $(34.64 \%)$. The unaffected animals were grazing side-by-side with the infected ones.

Cutaneous and ocular bovine demodicosis in cattle is locally known by cattle owners in Sudan as Um-Krush. According to the history given by the owners, the disease in some adult cattle persisted for 2-3 years, but none of the owners was able to identify these animals or give information regarding when the lesions initially appeared. The disease was not fatal and was observed in emaciated cattle as well as in animals in good bodily condition. All animals with a light or moderate infection showed no change in feeding, drinking or sexual behavior. However, all animals with severe infection and some with moderate infection preferred shaded areas, showed a marked reduction in food intake and milk yield, and had severe pruritus. Most of the animals with severe infection and some with moderate infection had fair to poor bodily condition.

Among the 300 cattle examined during the present study, 218 had simultaneously skin and eye infection whereas none of the infected cattle only had meibomian gland lesions (5). The skin and ocular symptoms observed in the examined animals have been previously described (5). The various classical forms of lesions were observed in skin (Figures 1 and 2) and meibomian glands.

\section{Parasitological findings}

Examination of crushed infected material from skin and meibomian gland lesions in all animals revealed an uncountable number of adult mites, eggs and molting stages of Demodex mites (Figure 3), pus and cell debris. The mites were successfully isolated and identified as Demodex bovis from skin (Figure 4) and $D$. ghanensis from meibomian gland lesions (5). Examination of eye impression smears and skin brushings from control non-infected cattle was negative for Demodex mites.

\section{Necropsy specimens}

Examination of the digested material of internal tissues, organs, glands and muscles was negative for Demodex mites. However, Demodex bovis and D. ghanensis mites were identified in the digested specimens of the skin and eyelids of the left eyes of infected cattle, respectively. All digested material including the skin and eyelids from non-infected cattle was negative for both mites.

\section{Bacteriological findings}

The culture of 300 specimens of infected material extracted from skin lesions revealed bacteria growth in 252 specimens although no bacterium was isolated from the remaining 48 specimens. Culture of 218 specimens of infected material expressed from meibomian gland lesions revealed growth in 128 specimens and no bacterium in the remaining 90 specimens (Table I). No bacterium was isolated from swab cultures of the eyes of non-infected cattle, and Gram-stained impression smears from the eyes of non-infected cattle showed insignificant numbers of microorganisms.

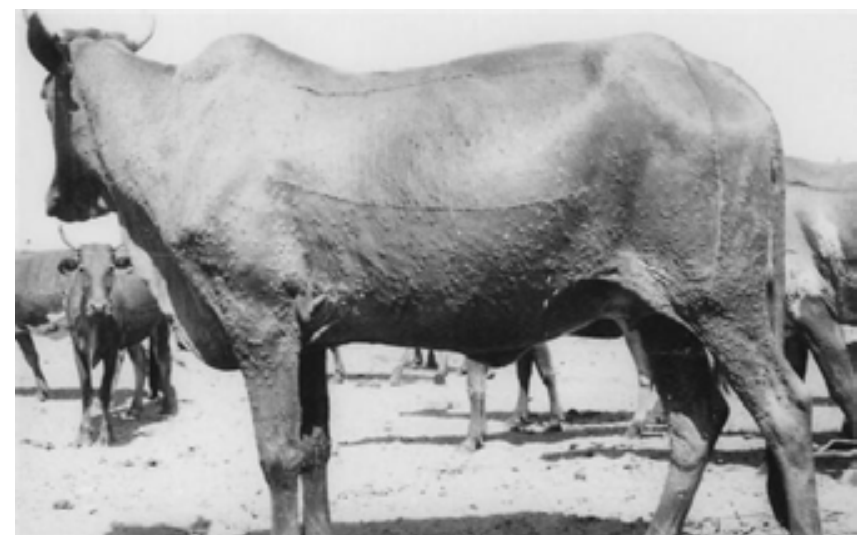

Figure 1: Cow showing numerous demodectic mange nodules mainly involving the lower half of the body.

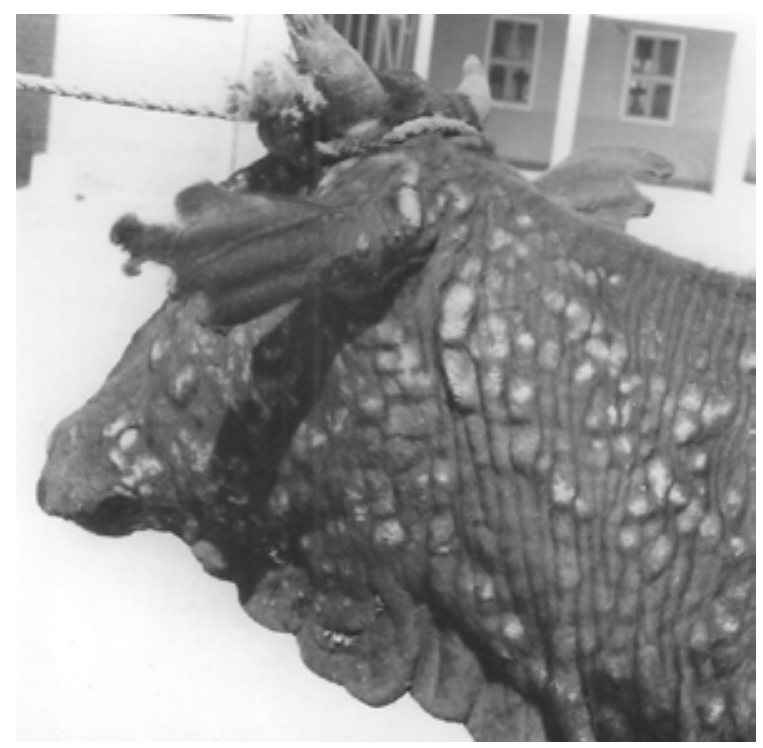

Figure 2: Demodectic mange pustules covered with thin white crusts involving the head neck and dewlap of a bull with generalized skin lesions of demodectic mange. Note: wrinkling and folding of the skin. 


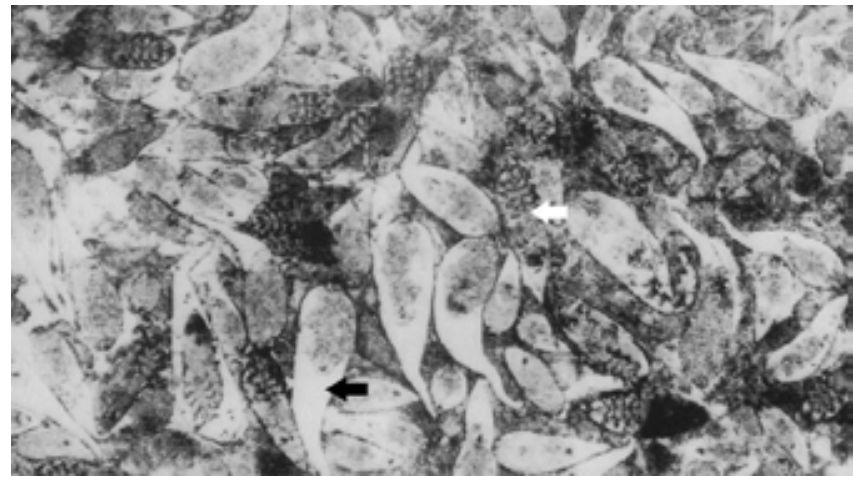

Figure 3: Numerous Demodex bovis mites (white arrow) showing different molting stages (black arrow) in a crushed specimen of infected purulent material extracted from skin lesions of demodectic mange. Scale bar: $70 \mu \mathrm{m}$.

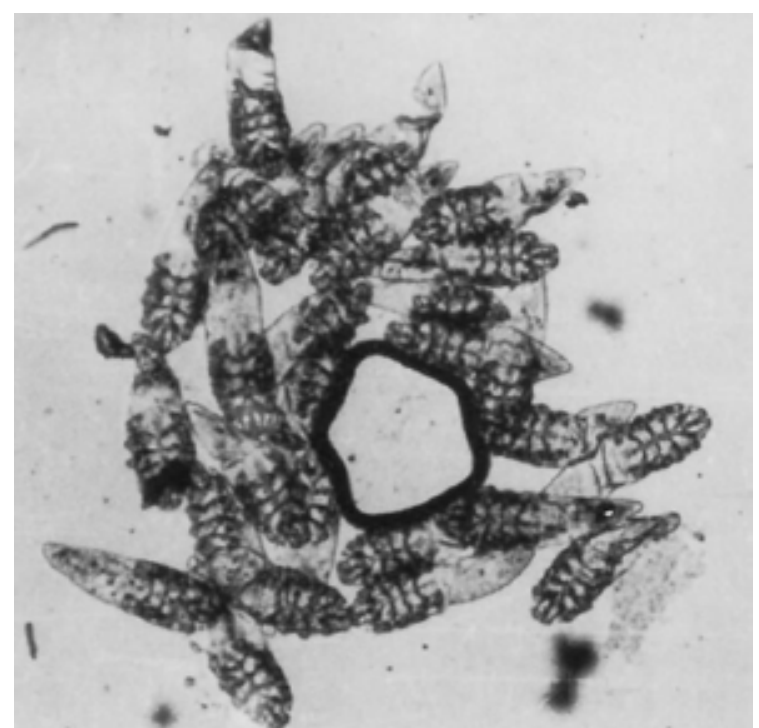

Figure 4: Cigar-shaped Demodex bovis mites isolated from infected material extracted from skin lesions of demodectic mange in cattle. Scale bar: $140 \mu \mathrm{m}$.

\section{Table I}

Bacteria isolated from skin and meibomian gland lesions of bovine demodicosis

\begin{tabular}{lcc} 
Bacteria isolated & \multicolumn{2}{c}{ Num. bacteria isolated } \\
\cline { 2 - 3 } & Skin lesions & $\begin{array}{c}\text { Meibomian } \\
\text { gland lesions }\end{array}$ \\
Moraxella bovis & - & 128 \\
Proteus vulgaris & 58 & - \\
Pseudomonas aeruginosa & 48 & - \\
Staphylococcus aureus & 80 & $26^{*}$ \\
Sta. epidermidis & 34 & - \\
Streptococcus pyogenes (group A) & 22 & - \\
Trueperella pyogenes** & 10 & - \\
No bacterium isolated & 48 & 90 \\
Total & 300 & 218
\end{tabular}

* Always present with Moraxella bovis; ** Formerly Arcanobacterium pyogenes, Actinomyces pyogenes, Corynebacterium pyogenes

\section{Pathological findings}

\section{Skin lesions}

The mites reached the hair bulb (Figure 5) by passing between the hair and the inner root sheath. They caused inflammation and dilatation of the orifices of the hair follicles and paved the way for active and/or passive introduction of pathogenic, commensal and opportunistic bacteria (Table I) in the hair follicles and sebaceous glands (pilosebaceous unit). The epithelial lining of the hair follicles became atrophied and the hair broke and fell out. The follicles became enlarged with replication of the mites, the blood vessels were dilated and the surrounding tissue was slightly infiltrated by lymphocytes and eosinophils (Figure 5).

Maximum distension of the hair follicles with mites, bacteria, pus, secretions and excretions resulted in the transformation of the pilosebaceous units to very enlarged cylindrical or saccular bladder-like cysts (colonies of demodectic mange), with one layer of an intact but jagged and extremely stretched epithelial lining. These cysts (colonies) were seen in the subepidermal and dermal layers. In many sections the cysts in the dermal layer had long ducts (sinus tracts) directed toward the surface of the skin (Figure 6), and on reaching the stratum papillare, the sinus tracts became shorter and broader and the colonies became extremely enlarged, utilizing the extra length of the sinus tract (Figure 7). The wall of these cysts showed moderate hyperplasia and was extremely jagged throughout its length (circumference). In many sections, the cysts communicated with the superficial epidermal layers which also showed marked hyperplasia and keratinization occluding the orifices of these colonies (bladder cysts) by a plug of epithelial cells and keratin (Figure 8). Liquefaction or breaking of the sealing plug of the cysts causes discharge of their contents onto the surface of the skin. In those areas there was acanthosis and scab formation. Under the scab, the epidermal layer showed severe degenerative and necrotic changes, and the subepidermal layer and dermal papillae were infiltrated by lymphocytes, macrophages, neutrophils and eosinophils.

More replication of the mites and associated bacteria resulted in much enlarged colonies with one layer of jagged and extremely stretched epithelial lining, surrounded by a thin layer of connective tissue. Partial or complete rupture of these cysts (colonies of demodectic mange) occurred discharging their contents in the

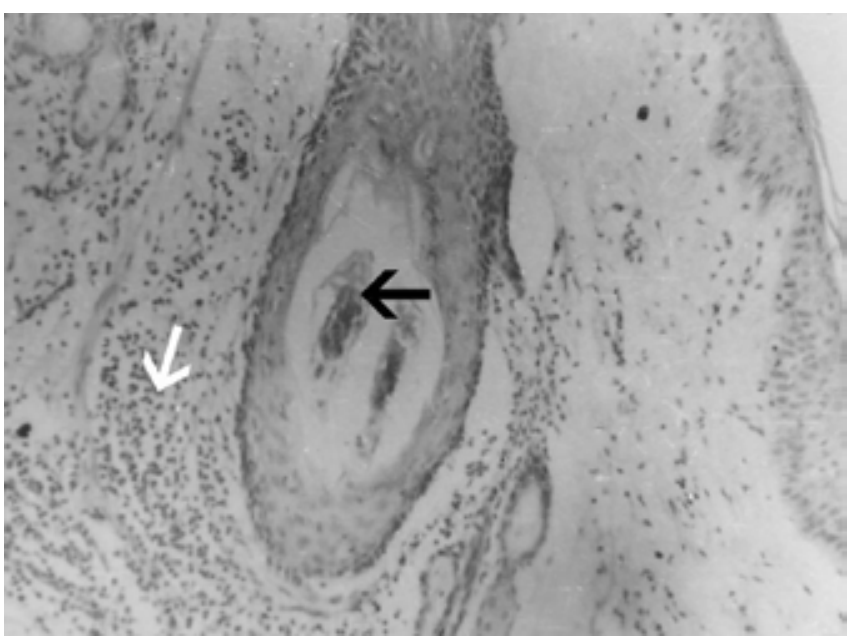

Figure 5: Section from the skin of a cow showing Demodex bovis mites in the hair bulb (black arrow). Note: dilatation of the hair bulb and infiltration by mononuclear cells in close proximity of the hair follicle (white arrow). Stained with hematoxylin and eosin. Scale bar: $150 \mu \mathrm{m}$. 
subepidermal and dermal layers. This produced exudative and productive lesions in areas where the contents of the colonies had come in direct contact with the elements of the surrounding connective tissue and evolved high-turnover granulomas with influx of macrophages and lymphocytes.

In areas where the contents of the ruptured cysts congregated (mites, pus and cell debris), the exudative lesions showed hemorrhage, marked infiltration by macrophages, lymphocytes, plasma cells, some eosinophils, epithelioid and few multinucleated giant cells showing degenerate mites (Figure 9). The productive lesions

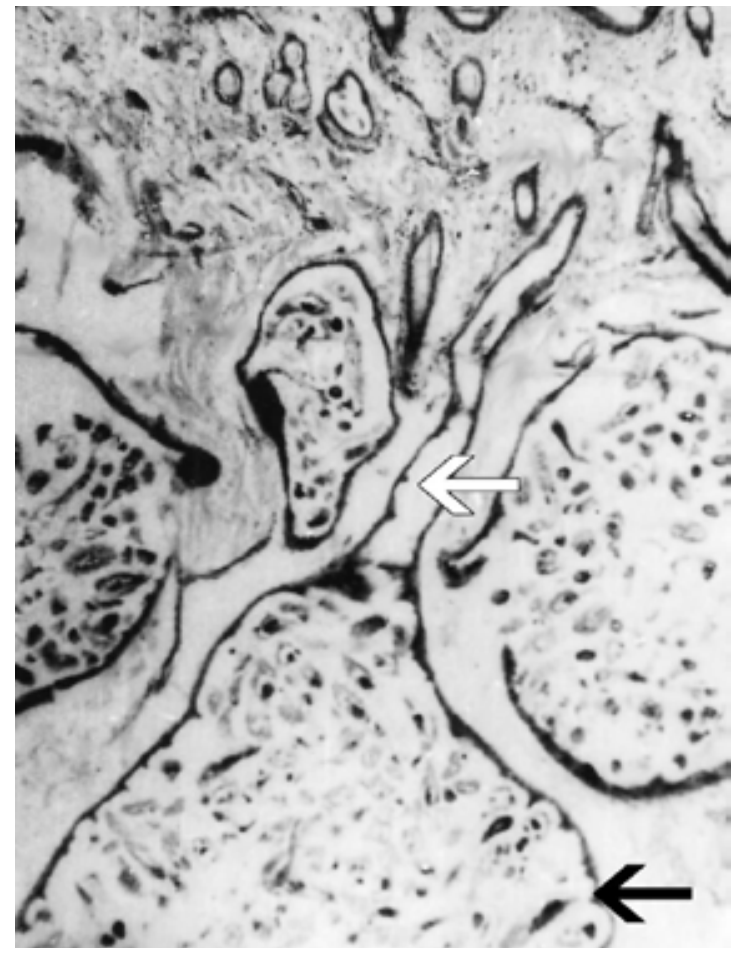

Figure 6: Enlarged saccular bladder-like cysts (colony of demodectic mange) in the dermal layer (black arrow) showing a thin jagged wall and a long duct (sinus tract) directed toward the surface of the skin (white arrow). Stained with hematoxylin. Scale bar: $300 \mu \mathrm{m}$.

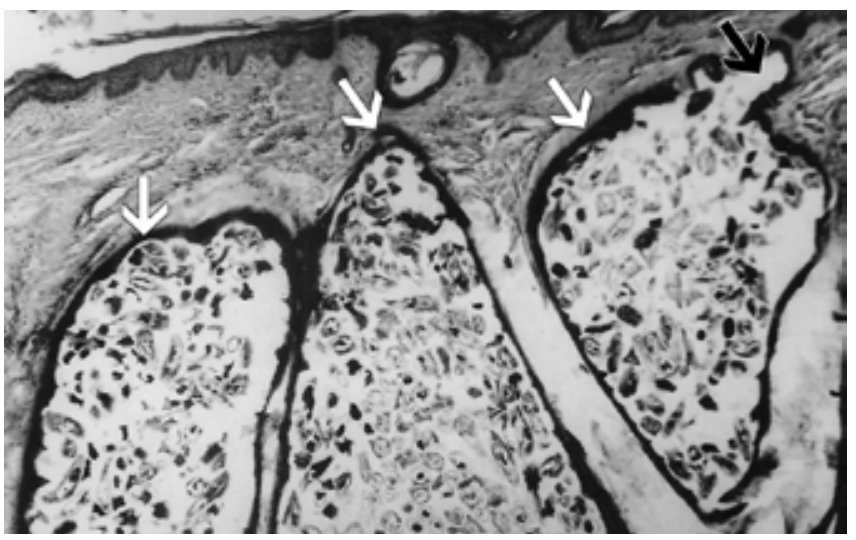

Figure 7: Skin sections from an infected cow showing pilosebaceous units transformed to enlarged cylindrical or saccular bladder-like cysts (colonies of demodectic mange) in the subepidermal layer (white arrows). Note: hyperplasia and jagging of the walls of the colonies and broad channel-like communication with the surface epidermal layers of the skin (black arrow). Stained with hematoxylin and eosin. Scale bar: $250 \mu \mathrm{m}$

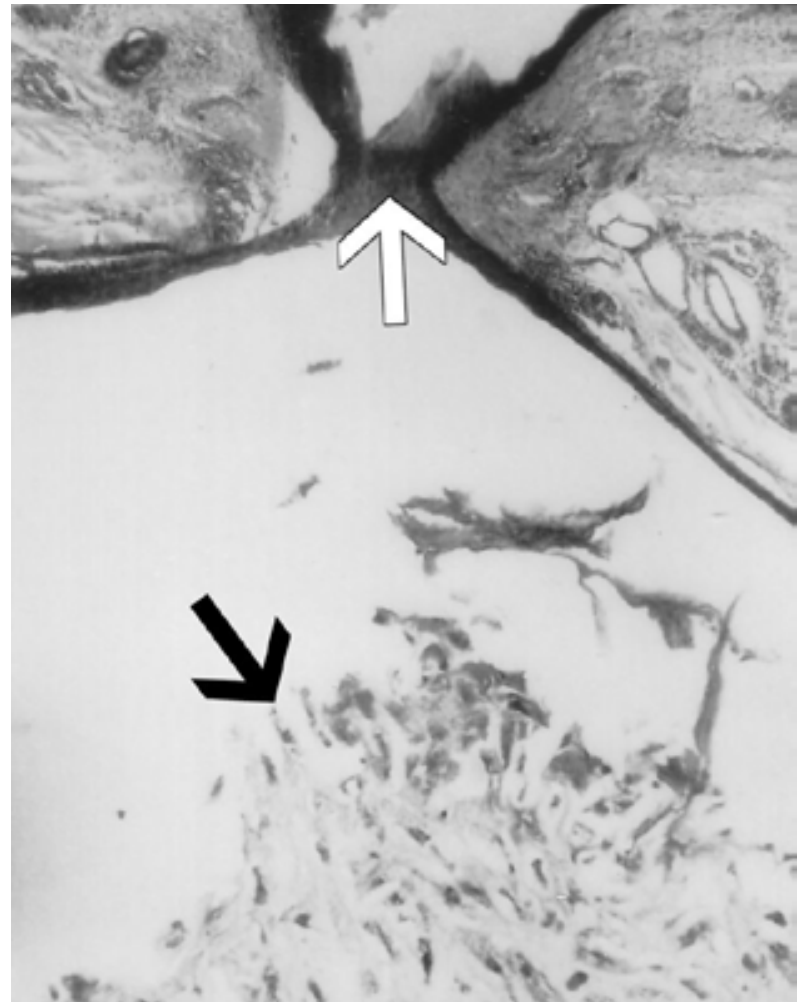

Figure 8: Skin section from a cow infected with demodectic mange showing enlarged bladder-like cysts distended with mites, pus and cell debris (black arrow) and communicating with the superficial epidermal layers. Note: occlusion of the orifice of the bladder cyst by a plug of epithelial cells and keratin (white arrow). Stained with hematoxylin. Scale bar: $250 \mu \mathrm{m}$.

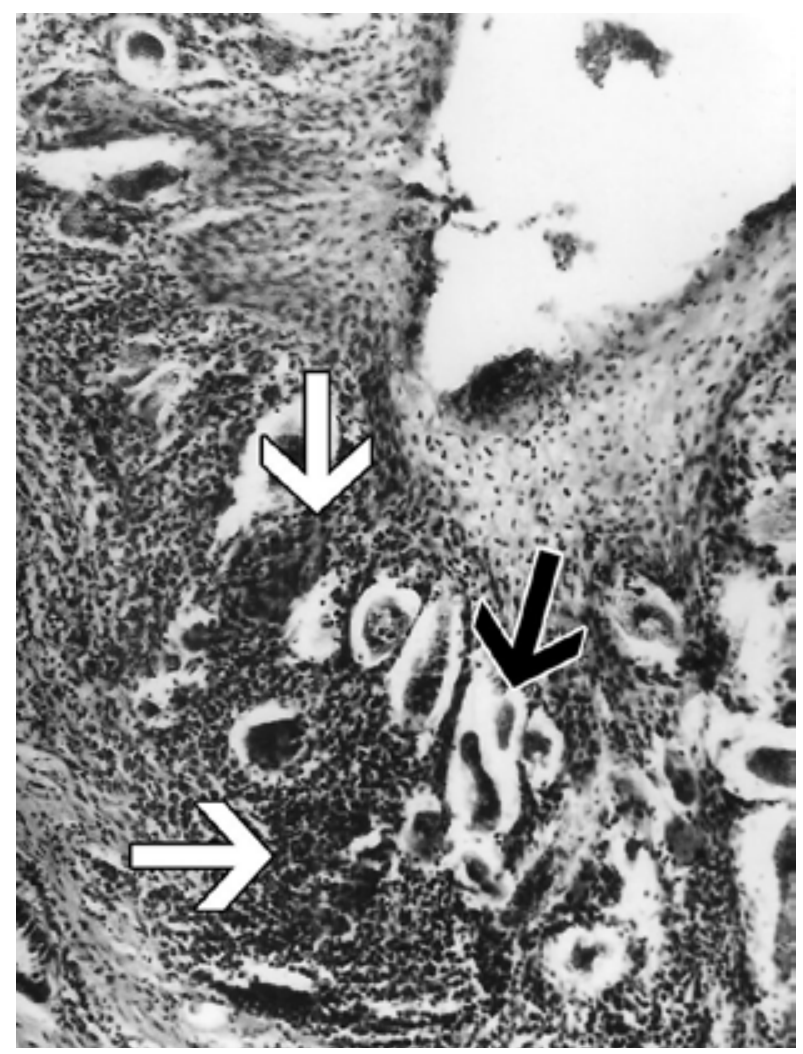

Figure 9: Exudative lesion of demodectic mange in the subepidermal and dermal layers of the skin of a cow showing a granulomatous reaction (white arrows) in the area where the contents of the ruptured cyst congregated (black arrow). Stained with hematoxylin and eosin. Scale bar: $250 \mu \mathrm{m}$. 
were exemplified by typical granulomas (Figure 10) in which the mites, bacteria, and purulent exudate of the ruptured cysts were surrounded by dominant proliferation of connective tissue, giant and epithelioid cells in the inner layers, and macrophages, lymphocytes, plasma cells, and few eosinophils in the outer layers. Remnants of mites were seen in the multinucleated giant cells. In other areas of the same section or in different sections there was regression and/or early healing of the lesions as inferred by the diffuse proliferation of connective tissue and degeneration of the granulomatous reaction. Skin sections from non-infected cattle showed no histopathological changes.

\section{mian gland lesions}

The histopathological observations regarding the eyelids of cattle with meibomian gland lesions have been previously detailed (5). The lesions of meibomian gland demodicosis produced by Demodex ghanensis were aggravated by Moraxella bovis and Sta. aureus. The pathogenesis and progress of the lesions from initial invasion of the main collecting tubules of the meibomian gland by the mite and bacteria to the stage of regression of the lesions have also been described (5).

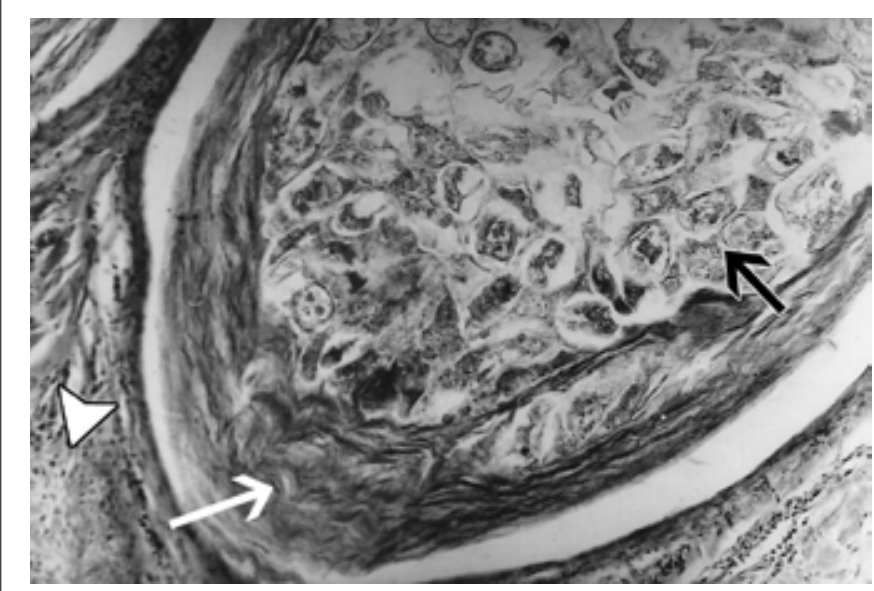

Figure 10: Typical granuloma in skin section from a cow infected with demodectic mange showing dominant proliferation of connective tissue (white arrow), epithelioid and giant cells in the inner layer with degenerate and fragments of Demodex mites (black arrow), and macrophages, lymphocytes, plasma cells and eosinophils in the outer layers (white arrow head). Stained with hematoxylin. Scale bar: $250 \mu \mathrm{m}$.

\section{DISCUSSION}

The current survey is probably the first report of a severe skin and simultaneous skin and meibomian gland demodicosis observed in a large number of cattle $(16,608)$. Previous workers only described skin $(3,35,42)$ or meibomian gland lesions $(21,24,37)$. The great majority of infected cattle $(87.7 \%)$ had visible clinical lesions which were highly suggestive of the disease. Accordingly, the disease was tentatively diagnosed from the clinical appearance of the lesions as demodectic mange. This finding is contrary to that of other authors who report that animals with numerous large lesions are uncommon, and the condition might pass without being suspected or diagnosed (34). It is also contrary to the findings of other authors $(28,34,35)$ who report that when the disease is mild it is unlikely to be diagnosed under ordinary circumstances, and the lesions are most readily seen in the dehaired-lime sulphide treated hides. In this study, only $12.3 \%$ of the infected animals had palpable lesions in the form of papules that were detected by palpation of the skin between the thumb and other fingers.

Calves and adult cattle of both sexes were found to be equally susceptible to the disease and the incidence in calves and adult cattle was similar. Calves had probably acquired infection from dams harboring persistent lesions of the disease for 2-3 years as gathered from the history given by the owners. This finding agrees with those of other authors $(23,29,31)$ who report that transmission of the mite usually occurs by direct contact from the dam to her offspring during nursing in the neonatal period, which explains why many cattle in contact or grazing side-by-side with infected ones were not infected. The mite acquired during the nursing period exists in harmony with the host, and it is only when equilibrium between the host and parasite is altered in favor of the mite that excessive proliferation occurs and lesions of demodectic mange are produced. Other authors $(6,7,22)$ also mention that rupture of the harmony between the host and the mite, which is part of the commensal flora of the skin, results in proliferation of the mite, and the appearance of lesions due to hereditary predisposition, stress, poor nutrition, concurrent diseases and any other factors that suppress immune function.

Although Demodex bovis and D. ghanensis were isolated from skin and meibomian gland lesions, respectively, in 218 cattle, it was interesting to report that none of the infected animals examined during the present study, as well as during the whole survey, had only meibomian gland demodicosis. This finding agrees with that of Fantahun et al. (22).

Demodex bovis was only found in the digested skin, and D. ghanensis was only found in the digested eyelids of infected cattle, but none of the mites was encountered in the digested internal tissues, organs, glands or muscles of the infected animals, indicating that neither mite had an endoparasitic phase. This finding agrees with those of other authors $(35,36,37,42)$, who examined the lymph nodes and internal organs of infected cattle, and report that $D$. bovis has no endoparasitic phase even in the most serious cases. However, some workers $(8,16)$ report the occurrence of $D$. canis in lymph nodes, internal organs and body fluids of dogs, and others $(46,47)$ found $D$. caprae in internal tissues, organs and body fluids of adult goats and their fetuses. In the authors' opinion, the mites observed were most probably dead and considered as foreign bodies transported to lymph nodes by the lymph.

Proteus vulgaris, Sta. aureus, Sta. epidermidis, and Streptococcus pyogenes (group A) were isolated from the infected purulent material extracted from skin lesions of infected cattle. The skin surface is probably the natural habitat of these bacteria which may alternatively belong to the intestinal flora existing in the surroundings of the animals as reported by some workers (39). These workers along with others $(30,31,39)$ report that the bacteria originate from bladder-like cysts (colonies of demodectic mange), which open toward the exterior; they liberate their contents onto the skin surface of infected animals and thus spread the infection as well as contaminate their surroundings. Pseudomonas aeruginosa, and Trueperella pyogenes (formerly Arcanobacterium pyogenes, Actinomyces pyogenes, Corynebacterium pyogenes) were also isolated from skin lesions of demodectic mange. Pseudomonas aeruginosa usually infects damaged tissues or tissues with reduced immunity, whereas $T$. pyogenes is one of the most common opportunistic pathogens of domestic ruminants capable of producing suppurative lesions in any organ or tissue in farm animals. Some workers $(17,26)$ report that these organisms produce a suppurative reaction and possess multiple virulence factors that cause serious damage resulting in marked deterioration of tissues. 
Moraxella bovis and Sta. aureus were isolated from the infected material extracted from meibomian gland lesions (5). M. bovis is an opportunistic pathogen and might have been acquired from surroundings as the animals might have been contaminated by ocular discharges from cattle infected with infectious keratoconjunctivitis. Morbidity from this organism is high, reaching epizootic proportions when transmission agents from infected cattle become available as reported by Radostits et al. (39), whereas Sta. aureus might have been acquired from the skin when the animals scratched or rubbed their irritated eyes against their bodies (5).

Histopathological examination of skin biopsy and eyelid samples from infected and non-infected cattle was conducted on qualitative rather than quantitative criteria. Variable histopathological changes were observed in different areas of the same section or in different sections. This enabled a detailed study of the pathology and pathogenesis of the disease from the stage of initial infection to that of regression and lesion healing.

Demodex bovis invaded the corium through the orifices of hair follicles and $D$. ghanensis invaded the meibomian glands through the orifices of main collecting tubules as previously observed (5, $35,36,37)$. The mites caused severe irritation by their movement and continuous gnawing and feeding on the follicular epithelium and/or glandular tissue (5). The secretions, excretions and somatic debris of the mites might have caused allergic and/or immunologic responses. The lesions were aggravated by pathogenic bacteria, including Sta. aureus and Str. pyogenes group A in skin lesions, and M. bovis and Sta. aureus in meibomian gland lesions. These bacteria produced various enzymes and toxins which exacerbated the lesions causing severe pruritus, resulting in scratching, rubbing, licking and gnawing at the affected areas. This resulted in more inflammation, damage of the infected areas and facilitated the invasion of further secondary and opportunistic bacteria (Proteus vulgaris, Pseudomonas aeruginosa, Sta. epidermidis, and Trueperella pyogenes) which produced a suppurative reaction complicating the lesions.

The occlusion of the orifices of hair follicles and main collecting tubules of the meibomian glands created conditions highly conducive to mite and bacterial multiplication. The severe inflammatory response caused distortion of the meibomian glands (5) and hair follicles which were transformed to enlarged bladder-like cysts (demodectic mange colonies), and resulted in marked dilatation and damage to the main collecting tubules and ducts of the meibomian glands (5). The breaking or liquefaction of the sealing plug of demodectic mange colonies which opened onto the skin surface might be caused by the increased pressure within the distended colonies and/or by the action of hyaluronidase enzymes produced by pathogenic bacteria. Damage of weak spots in the wall of the colonies or their complete destruction and liberation of their contents in surrounding tissues, and seeping-out contents from main collecting tubules and ducts of meibomian glands in surrounding tissues of the eyelids (5) resulted in a severe inflammatory response. The histopathological changes observed in skin sections were more severe than those previously described $(31,35)$, and the changes observed in meibomian gland sections were similar (5) but also more severe than reported by other workers $(22,24,37)$.

As mentioned above, Sta. aureus and Str. pyogenes group A, Proteus vulgaris, Pseudomonas aeruginosa Sta. epidermidis and $T$. pyogenes were isolated from skin lesions of demodectic mange, and $M$. bovis and Sta. aureus were isolated from meibomian gland lesions. These bacteria produce toxins and enzymes $(12,13$, $17,18,25,26)$ that aggravate lesions caused by Demodex mites, resulting in marked deterioration of the skin and meibomian glands (5). They also produce severe histopathological changes which are highly compatible with cell-mediated immunity. Authors report that on the basis of histopathological investigations an immunological response to the parasite seems to be involved (40). In this study, the liberation of the contents of bladder-like cysts in the subepidermal and dermal layers of the skin and main collecting tubules of the meibomian glands (5) in the surrounding connective tissue evoked severe histopathological changes characterized by massive high-turnover granulomatous reaction with influx of macrophages and lymphocytes, proving that Demodex mites and associated bacteria were both persistent and immunogenic, as previously mentioned $(5,19,45)$. This resulted in the severe and progressive disease that has been encountered in natural field cases.

The histopathological changes recorded in this study were comparable and similar to those described by other workers in cattle, dogs and humans. Authors report that the granulomatous reaction observed in cattle suggests a progressive disease $(5,22)$. In dogs dilatation of the hair follicles with mites, folliculitis, perifolliculitis furunculosis, and granulomas resulting from damage to hair follicles and liberation of $D$. canis in the extra-follicular space have been observed $(6,43)$. In humans Demodex folliculorum and $D$. brevis infections cause hyperkeratinization and epithelial hyperplasia resulting in follicle blockage, induce a foreign body granulomatous reaction, and stimulate host humoral and cell-mediated immune reactions (7).

\section{Acknowledgments}

The authors are indebted to the Agricultural Research Council, National Council for Research, Khartoum, Sudan, for the generous support of this work. Dr W.N. Beesley, formerly Head of the Department of Veterinary Parasitology, Liverpool School of Tropical Medicine, UK, is gratefully acknowledged for his interest in this work and for the confirmation of the identification of Demodex bovis mites. The confirmation of the identification of $D$. bovis and D. ghanensis by the late Pr W.B. Nutting, Department of Zoology, University of Massachusetts, USA, is highly appreciated and acknowledged with thanks.

\section{REFERENCES}

1. ABU-SAMRA M.T., 1980. A new skin biopsy technique in domestic animals. Zentralbl. Veterinarmed. A, 27: 614-617.

2. ABU-SAMRA M.T., AZIZ M.A., SALIH A.K., 1984. A new technique for the isolation of Demodex bovis from preserved infected material. Ann Trop. Med. Parasitol., 78: 319-321.

3. ABU-SAMRA M.T., IMBABI S.E., MAHGOUB E.S., 1981. Mange in domestic animals in the Sudan. Ann. Trop. Med. Parasitol., 75: 627-637.

4. ABU-SAMRA M.T., MAHGOUB A.K., BEESLEY W.N., 1984. Demodicosis in Sudanese cattle. Trans. R. Soc. Trop. Med. Hyg., 78: 271.

5. ABU-SAMRA M.T., SHUAIB Y.A., 2014. Meibomian gland demodicosis in cattle: the clinical disease and diagnosis. Inter. J. Vet. Sci., 3: $11-17$.

6. AUJLA R.S., SINGLA L.D., JUYAL P.D., GUPTA P.P., 2000. Prevalence and pathology of mange-mite infestations in dogs. J. Vet. Parasitol., 14: 45-49.

7. BAIMA B., STICHERLING M., 2002. Demodicidosis revisited. Acta Derm. Venereol., 82: 3-6.

8. BAKER K.P., 1969. The histopathology and pathogenesis of demodecosis of the dog. J. Comp. Pathol., 79: 321-327.

9. BANCROFT J.D., HARRY C.C., 1994. Manual of histological techniques and their diagnostic application, 2nd Edn. New York, USA Churchill Livingstone, 457 p.

10. BARROW G.I., FELTHAM R.K.A., Eds, 1993. Cowan and Steel's manual for the identification of medical bacteria, 3rd Edn. Cambridge, UK, Cambridge University Press, $351 \mathrm{p}$. 
11. BIKOWSKI J.B., DEL ROSSO J.Q., 2009. Demodex dermatitis: a retrospective analysis of clinical diagnosis and successful treatment with topical crotamiton. J. Clin. Aesthet. Derm., 2: 20-25.

12. BISNO A.L., BRITO M.O., COLLINS C.M., 2003. Molecular basis of group A streptococcal virulence. Lancet Infect. Dis., 3: 191-200.

13. BROWN M.H., BRIGHTMAN A.H., FENWICK B.W., RIDER M.A., 1998. Infectious bovine keratoconjunctivitis: a review. J. Vet. Intern Med., 12: 259-266.

14. BUKVA V., 1986. Demodex tauri sp. n. (Acari: Demodicidae), a new parasite of cattle. Folia Parasitol. (Praha.), 33: 363-369.

15. CHAKRABARTI A., 1984. Some epidemiological features of bovine demodicosis. Indian J. Vet. Med., 4: 80-83. 16. CHAKRABARTI A., MISRA S.K., 1978. Studies on the pathology of
Demodex canis Leydig (1859) in the internal organs of canines. Indian I. Anim. Sci., 48: 466-468.

17. COLLINS M.D., CUMMINS C.S., 1986. Genus Corynebacterium Lehmann and Neumann, 1896, 350 AL. In: Sneath P.H.A., Mair N.S. Sharpe M.E., Holt J.G., Eds, Bergey's manual of systematic bacteriology, Vol. 2. Baltimore, MD, USA, Williams \& Wilkins, p. 1266-1276.

18. DAVIDSON H.J., STOKKA G.L., 2003. A field trial of autogenous Moraxella bovis bacteria administered through either subcutaneous or subconjunctival injection on the development of keratoconjunctivitis in a beef herd. Can. Vet. J., 244: 577-580.

19. DICK H.M., WILKINSON P., POWIS S., 1983. The normal immune system. In: Wilson G., Dick H.M., Eds., Topley and Wilsons' principles of bacteriology, virology and immunity, 7th Edn, Vol. 1: General microbiology and immunity. London, UK, Edward Arnold, p. 296-318.

20. ENGLISH F.P., IWAMOTO T., DARRELL R.W., DEVOE A.G., 1970 The vector potential of Demodex folliculorum. Arch. Ophthalmol., 84 83-85.

21. ESURUOSO G.O., 1977. Bovine demodicosis in Southern Nigeria. Bull. Anim. Health Prod. Afr., 25: 65-72.

22. FANTAHUN T., YIGSAW T., CHANIE M., 2012. Bovine demodecosis threat to leather industry in Ethiopia. Asian J. Agric. Sci., 4: 314-318.

23. FISHER W.F., MILLER R.W., EVERETT A.L., 1980. Natural transmission of Demodex bovis Stiles to dairy calves. Vet. Parasitol., 7 233-241.

24. GEARHART M.S., CRISSMAN J.W., GEORGI M.E., 1981. Bilateral lower palpebral demodicosis in a dairy cow. Cornell Vet., 71: 305-310.

25. HESS J.F., ANGELOS J.A., 2006. The Moraxella bovis RTX toxin locus mbx defines a pathogenicty island. J. Med. Microbiol., 55: 443-449.

26. JOST B.H., BILLINGTON S.J., 2005. Arcanobacterium pyogenes: molecular pathogenesis of an animal opportunist. Antonie Leeuwenhoek, 88: $87-102$

27. KAUFMANN J., 1996. Parasitic infections of domestic animals: a diagnostic manual. Basel, Switzerland, Birkhäuser Verlag, 423 p.

28. KIRKWOOD A., KENDALL S.B., 1966. Demodectic mange in cattle. Vet. Rec., 78: 33-34.

29. MARTINELLE L., DAL POZZO F., LOSSON B., SARRADIN P. SAEGERMAN C., 2011. Demodicosis in two Holstein young calves. Parasite, 18: 89-90.
30. MATTHES H.F., 1994. Investigations of pathogenesis of cattle demodicosis: sites of predilection, habitat and dynamics of demodectic nodules. Vet. Parasitol., 53: 283-291.

31. MAXIE M.G. Ed., 2007. Jubb, Kennedy and Palmer's pathology of domestic animals, Vol. 1, 5th Edn. Amsterdam, Netherlands, Elsevier/ Saunders, $932 \mathrm{p}$

32. MILNES A., MITCHELL S., BELL S., 2012. Emerging skin conditions in cattle. In Practice, 34: 588-597.

33. MULLEN G.R., OCONNOR B.M., 2009. Mites (Acari). In: Mullen G.R., Durden L.A., Eds., Vol. 2, Medical and veterinary entomology. Burlington, MA, USA, Elsevier, p. 433-492.

34. MURRAY M.D., NUTTING W.B., HEWETSON R.W., 1976. Demodectic mange of cattle. Aust. Vet. J., 52: 49.

35. NEMESERI L., SZEKY A., 1961. Demodicosis in cattle. Acta Vet. Acad. Sci. Hung., 11: 209-221.

36. NUTTING W.B., 1976. Hair follicle mites (Demodex spp.) of medical and veterinary concern. Cornell Vet., 66: 214-231.

37. NUTTING W.B., KETTLE P.R., TENQUIST J.D., WHITTEN L.K., 1975. Hair follicle mites (Demodex spp.) in New Zealand. N. Z. J. Zool., 2: 219-222.

38. OIE, 2013. Mange. In: Manual of diagnostic tests and vaccines for terrestrial animals. Paris, France, OIE, chapter 2.9.8.

39. RADOSTITS O.M., GAY C.C., HINCHCLIFF K.W., CONSTABLE P.D., 2007. Veterinary medicine: A textbook of the diseases of cattle, horses, sheep, pigs and goats. 10th Edn. Edinburgh, UK, Saunders/Elsevier, 2156 p.

40. RUFLI T., MUMCUOGLU Y., 1981. The hair follicle mite Demodex folliculorum and Demodex brevis: biology and medical importance. A review. Dermatologica, 162: 1-11

41. SLINGENBERGH J., MOHAMMED A.N., BIDA S.A., 1980. Studies on bovine demodecosis in northern Nigeria. Vet. Q., 2: 90-94.

42. SMITH H.J., 1961. Bovine demodicidosis. II. Clinical manifestations in Ontario. Can. J. Comp. Med. Vet. Sci., 25: 201-204.

43. SOOD N.K., MEKKIB B., SINGLA L.D., GUPTA K., 2012. Cytopathology of parasitic dermatitis in dogs. J. Parasit. Dis., 36: 73-77.

44. SOULSBY E.J.L., 1982. Helminths, arthropods and protozoa of domesticated animals 7th Edn. London, UK, Bailliere Tindall, 809 p.

45. THOMSON R.G., 1978. General veterinary pathology. Philadelphia, PA, USA, W.B. Saunders, 463 p.

46. VENKATESAN R.A., 1980. Significance on the presence of Demodex caprae in the internal organs of goats. Cheiron, 9: 15-21.

47. VENKATESAN R.A., NANDY S.C., KRISHNAN G., 1979. Occurrence and possible significance of demodectic mites, Demodex caprae, in the internal tissues of fetal and adult Indian goats. J. Am. Leather Chem. Assoc., 74: 191-197.

Accepted 21 January 2015; Online publication March 2015 


\section{Résumé}

Abu-Samra M.T., Shuaib Y.A. Pathologie et pathogenèse de la démodécie cutanée et de la glande de Meibomius chez des bovins

Une enquête nationale menée au Soudan sur la démodécie bovine a concerné 48000 animaux examinés soit au cours de campagnes de vaccination (44 800), soit lors d'inspections ante et post mortem dans des abattoirs (3 200). Sur l'ensemble des animaux enquêtés, 44908 étaient des adultes (2-8 ans) dont 34,6 p. 100 étaient infectés, et 3092 étaient des veaux ( $<2$ ans) dont 34,6 p. 100 étaient infectés. Trois cents bovins affectés par des lésions cutanées graves, dont 218 présentaient également des lésions de la glande de Meibomius, ont été sélectionnés. Les tableaux cliniques de la démodécie cutanée et de la démodécie de la glande de Meibomius ont été décrits. Proteus vulgaris, Pseudomonas aeruginosa, Staphylococcus aureus, Sta. epidermidis, Streptococcus pyogenes (groupe A) et Trueperella pyogenes ont été isolés dans les lésions cutanées, et Moraxella bovis et Sta. aureus I'ont été dans les lésions de la glande de Meibomius. Ces bactéries produisaient des toxines et des enzymes qui aggravaient les lésions causées par les acariens Demodex bovis et $D$. ghanensis, respectivement dans la peau et dans les glandes de Meibomius. Aucun de ces acariens n'a été retrouvé dans les tissus internes ni dans les organes, indiquant qu'il n'y a pas eu de phase endoparasitaire. Les modifications histopathologiques observées étaient liées à l'immunité à médiation cellulaire. L'écoulement du contenu des colonies de Demodex dans les couches sous-épidermique et dermique, et dans les tissus environnant les glandes de Meibomius a entraîné des modifications histopathologiques sévères, caractérisées par le renouvellement continu des réactions granulomateuses avec afflux de macrophages et de lymphocytes. La pathogenèse de la maladie a été décrite du stade d'invasion initiale des follicules pileux et des tubes collecteurs des glandes de Meibomius par les acariens et les bactéries associées, au stade de régression des lésions. Il a été conclu que la nature de l'association entre les acariens Demodex et les bactéries dans les lésions démodéciques était synergique et que les deux agents pathogènes avaient la même importance. Le renouvellement continu des réactions granulomateuses qui caractérisaient les modifications histopathologiques a montré que les Demodex et les bactéries associées étaient persistants et immunogènes.

Mots-clés : Bovin - Demodex - Gale démodécique - Glande sébacée - Peau - Bactériose - Pathogenèse - Soudan.

\section{Resumen}

Abu-Samra M.T., Shuaib Y.A. Patología y patogénesis de la demodicosis bovina en piel y glándulas de Meibomio

Se llevó a cabo una encuesta nacional de la demodicosis bovina en 48,000 cabezas de ganado en Sudan durante campañas de vacunación $(44,800)$ y durante exámenes ante mortem y post mortem en mataderos (3200). Entre el total encuestado, 44,908 fueron adultos (2-8 años) de los cuales 34,6\% estaban infectados y 3092 fueron terneros $(<2$ años $)$ de los cuales $34,6 \%$ estaban infectados. Se seleccionaron trescientas cabezas con lesiones de piel severas, entre los cuales 218 también presentaban lesiones de la glándula de Meibomio. Se describieron las fotos clínicas de demodicosis en piel y de glándula de Meibomio. Proteus vulgaris, Pseudomonas aeruginosa, Staphylococcus aureus, Sta. epidermidis, Streptococcus pyogenes (grupo A) y Trueperella pyogenes fueron aislados en lesiones de piel y Moraxella bovis y Sta. aureus fueron aislados en lesiones de glándulas de Meibomio. Estas bacterias produjeron toxinas y enzimas dañinas, agravando las lesiones causadas por ácaros de Demodex bovis and D. ghanensis en piel y glándulas de Meibomio respectivamente. Ninguno de los ácaros se encontró en órganos o tejidos internos, indicando que no había fase endo parasita. Los cambios histopatológicos observados fueron correspondientes con la inmunidad mediada por células. La liberación del contenido de las colonias de sarna demodéctica hacia las capas sub epidérmicas y dérmicas de la piel y el tejido conectivo adyacente de las glándulas de Meibomio, evocaron cambios histopatológicos severos, caracterizados por reacciones granulomatosas masivas y de alta rotación con flujo de macrófagos y linfocitos. Se describe la patogénesis de la enfermedad, desde el estadio de invasión inicial por los ácaros y bacterias asociadas de los folículos pilosos y túbulos colectores de las glándulas de Meibomio hasta el estadio de regresión de las lesiones. Se concluye que la naturaleza de la asociación entre los ácaros de Demodex y las bacterias en las lesiones de sarna demodectica fue sinergística y de igual importancia. Las lesiones granulomatosas de alta rotación que caracterizaron los cambios histopatológicos mostraron que los ácaros de Demodex y las bacterias asociadas fueron persistentes e inmunogénicos

Palabras clave: Ganado bovino - Demodex - Sarna - Glándula sebácea - Piel - Bacteriosis - Patogénesis - Sudan. 
